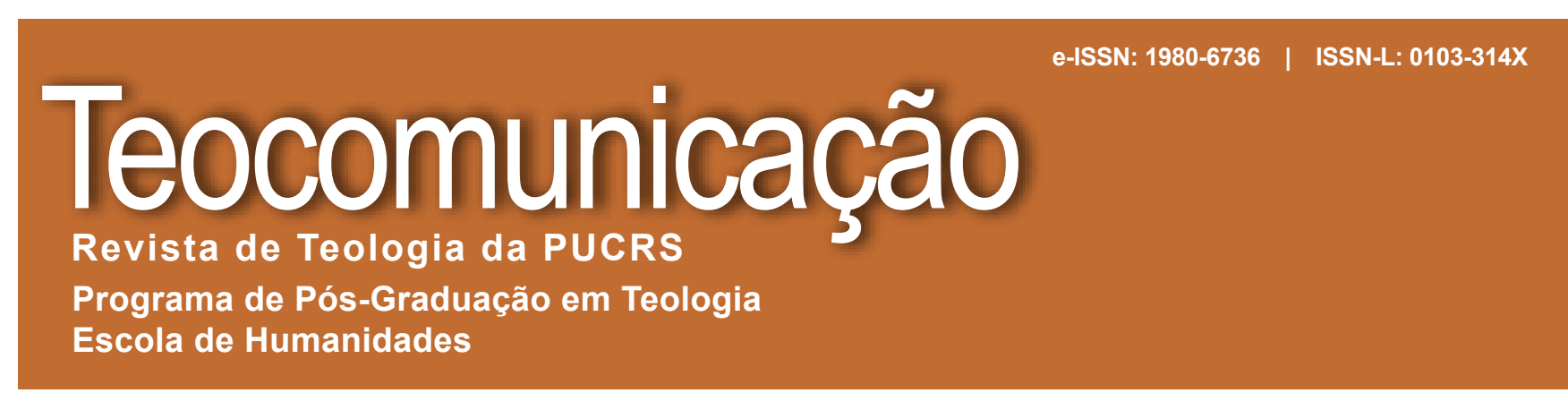

Porto Alegre, v. 49, n. 2, julho-dezembro 2019 e36592

http://dx.doi.org/10.15448/0103-314X.2019.2.36592

EDITORIAL

\title{
Santidade e responsabilidade pública
}

\section{Holiness and public responsibility}

\author{
Rafael Martins Fernandes ${ }^{1}$
}

O contexto da sociedade plural tem lançado aos cristãos sérios desafios para a vivência da santidade. O fiel, que queira levar a sério o Evangelho, pode ser visto por muitos como um neurótico na área da moral sexual e, por outros, como um comunista no campo econômico e social. O seu amor responsável pelo mundo - manifestado na fidelidade matrimonial, na simplicidade de vida e partilha de bens - causa não poucas vezes incompreensões dos contemporâneos que não compartilham da mesma fé. $\mathrm{O}$ generalizado estilo de vida hedonista e relativista presente na sociedade globalizada contribui para que esse amor responsável anunciado por cristãos apareça, em muitas ocasiões, tão e simplesmente como uma bela utopia, sem incidência no mundo real.

É importante dizer que as comunidades cristãs têm reagido positivamente frente aos desafios da secularização, não sem recair, em momentos e lugares diferentes, em visões parciais da renovação da vida cristã. A atual polarização de ideias, verificada no confronto entre diferentes setores da Igreja, comprova a dificuldade de estabelecer uma equilibrada compreensão da vivência da santidade no interior da relação Igreja-mundo: de um lado, há os cristãos que promovem, diante da sensação de estranhamento da realidade, uma nova fuga mundis; porém, diferente dos antigos monges anacoretas. Encerram-se em grupos afins, de caráter elitista, almejando uma outra condição frente ao mundo. Ao buscar um tipo de perfeição moral, de cunho individual, distanciam-se daqueles que se encontram moralmente à margem da proposta cristã. Contudo, esse tipo de anseio escatológico não nasce da misericórdia, nasce da rejeição à condição humana ${ }^{2}$ (verticalismo da salvação). De outro lado, existem voluntariosos que se inserem nas diferentes realidades do mundo, porém, sucumbem frente o fascínio das conquistas científicas, sociais e políticas. Ao ingressarem nessas realidades, sem o exercício humilde do discernimento evangélico, deixam-se contagiar pelo ambiente relativista, perdendo a sua própria identidade cristã. Nesse caso, o conceito de santidade, portador de um significado transcendente, tende a ser relegado ao esquecimento (horizontalismo da salvação).

Pontifícia Universidade Católica do Rio Grande do Sul (PUCRS), Bolsista CAPES, PNPD, Pós-graduação em Teologia, Porto Alegre, RS, Brasil. E-mail: rafael.martins@pucrs.br - ORCID iD: http://orcid.org/0000-0003-2416-4862

Cf. BINGEMER, Maria Clara. Santidade: chamado à humanidade, p. 75. Ver também o capítulo segundo da Exortação Apostólica de Papa Francisco Gaudete et exsultate. 
Como indica a palavra católico (universal) ${ }^{3}$, a fé cristã só pode ser compreendida em sua profundidade quando estiver inserida em uma visão que contemple a totalidade da vida e do mistério cristão. O católico, pela sua própria natureza, afasta-se das compreensões parciais da realidade. Nesse sentido, o binômio "santidade e responsabilidade", proposto como reflexão nuclear desta edição da Teocomunicação, questiona a atual polarização da compreensão da vivência cristã, chamando a atenção para a unidade entre o ser e o agir dos cristãos no coração da Igreja e do mundo. Não existe santidade sem um agudo senso de responsabilidade pelas realidades terrestres, bem como não há autêntica responsabilidade cristã pelo mundo sem a fé no Deus Criador e Redentor.

A noção de responsabilidade contribui para a correta compreensão da vivência da santidade. Segundo o dicionário Houaiss, responsabilidade quer dizer "obrigação de responder pelas ações próprias ou dos outros; caráter ou estado do que é responsável". Na etimologia dessa palavra encontra-se o antepositivo espos, "de uma raiz indo-europeia spend-fazer uma libação [...] firmar um tratado [...] e em lat. pelo v. spondeo,es,spopondi,sponsum,spondere 'assumir um compromisso ou uma obrigação solene"". . Da raiz espos, derivam também os termos esposo e desposar, que conferem as ideias de promessa, de compromisso e de caráter sagrado às obrigações firmadas.

As alianças que Deus estabeleceu com Noé, Abraão, Moisés, os profetas e, finalmente, em seu Filho Jesus Cristo, corroboram o sentido da responsabilidade como um tratado solene, de caráter sagrado, com o qual Deus manifesta a sua fidelidade pelo mundo. Aqui, a santidade - marca característica do próprio Deus - não se opõe ao mundo, mas o abraça e o eleva à condição divina. A encarnação, morte e ressurreição de Jesus Cristo revela com estupenda claridade a seriedade com a qual Deus assumiu responsavelmente a nossa frágil condição humana. De modo especial, a morte de Jesus Cristo na cruz, realizada na parte de fora dos muros da Cidade Santa, indica outrossim que a santificação da humanidade foi realizada uma vez por todas para além de nossa limitada compreensão sobre a santidade divina. Fora dos confins do Templo - o lugar do Santo dos Santos - a Trindade esparramou o seu divino amor responsável pelo mundo. O fiel, que leva a sério o caso da cruz do Filho de Deus, segue por esse mesmo caminho - de incompreensões -, assumindo amorosa e responsavelmente as realidades sociopolíticas e culturais que o cercam.

\section{REFERÊNCIAS}

BINGEMER, Maria Clara. Santidade: chamado à humanidade. Reflexões sobre a Exortação Apostólica Gaudete et exsultate. São Paulo: Paulinas, 2019.

HOUAISS, Antônio; VILLAR, Mauro de Salles. Responsabilidade. Dicionário Houaiss da língua portuguesa. Rio de Janeiro: Objetiva, 2001. https://doi.org/10.17979/rlex.2003.9.0.5582

KASPER, Walter. A Igreja Católica: essência, realidade, missão. Trad. Nélio Schneider. São Leopoldo: UNISINOS, 2012.

PAPA FRANCISCO, Exortação Apostólica Gaudete et exsultate: sobre o chamado à santidade no mundo atual. São Paulo: Paulus, 2018.

\footnotetext{
3 No seu “sentido original, a palavra ‘católico' justamente não tinha qualquer sentido demarcatório; bem pelo contrário, ela se referia ao universal e à totalidade que é mais do que a soma das suas partes. 'Católico' queria dizer integralidade no sentido de plenitude" (KASPER, Walter. A Igreja Católica, p. 230).

4 HOUAISS, Antônio; VILLAR, Mauro de Salles. Responsabilidade. In: Dicionário Houaiss da língua portuguesa.
} 
Recebido em: 03/12/2019

Aceito em: 03/12/2019

Publicado: 29/12/2019

Endereço:

Rafael Martins Fernandes

Seminário Maior N. Sra. da Conceição, Av. Senador Salgado Filho, 7100, Bairro Jardim Lisboa, Viamão, RS, Brasil - CEP: $94440-000$ 